\title{
Analisis Hukum Terhadap Penumpang Pesawat Atas Keterlambatan Keberangkatan Penerbangan Domestik di Bandara Internasional Kualanamu Deli Serdang
}

\section{Legal Analysis of Aircraft Passengers for Departure Delay Domestic in International Airport Kualanamu Deli Serdang}

\author{
Sartika Yuli, Taufik Siregar \& M. Citra Ramdhan* \\ Program Studi Magister Ilmu Hukum, Universitas Medan Area, Indonesia
}

Diterima: 13 Juni 2021; Direview: 31 Juli 2021; Disetujui: 30 September 2021

\begin{abstract}
*Coresponding Email: citra@staff.uma.ac.id
Abstrak

Tujan penulisan penelitian ini untuk mengkaji aturan hukum tentang maskapai penerbangan untuk pesawat penumpang di Indonesia yaitu Undang-Undang No. 8 tahun 1999 tentang Perlindungan Konsumen, Undang-Undang No. 1 Tahun 2009 tentang Penerbangan dan Peraturan Menteri Perhubungan No. 89 Tahun 2015 tentang Penanganan Keterlambatan Pada Badan Usaha Angkutan Udara Niaga Berjadwal Di Indonesia dan Peraturan Menteri Perhubungan Nomor 92 Tahun 2011 perubahan atas Peraturan Menteri Perhubungan No. 77 Tahun 2011 tentang Tanggung Jawab Pengangkut Angkutan Udara. Faktor-faktor penyebab terjadinya keterlambatan keberangkatan adalah salah satunya faktor cuaca, dan masalah teknis pada pesawat tapi yang lebih sering disebabkan karena cuaca. Tanggung jawab maskapai penerbangan domestik terhadap penumpang pesawat yang mengalami keterlambatan keberangkatan di Bandara Internasional Kualanamu Deli Serdang adalah dengan memberikan konpensasi dan ganti rugi yaitu berupa minuman ringan, makanan ringan dan makanan berat serta uang ganti rugi, tergantung jenis keterlambatan menurut kategorinya yaitu: Kategori 1, keterlambatan 30 sampai 60 menit, Kategori 2, keterlambatan 61 sampai 120 menit, Kategori 3, keterlambatan 121 sampai 180 menit, Kategori 4, keterlambatan 181 sampai 240 menit, Kategori 5, keterlambatan lebih dari 240 menit, Kategori 6, yaitu pembatalan penerbangan, maka maskapai penerbangan wajib mengalihkan ke penerbangan berikutnya atau mengembalikan seluruh biaya tiket (refund).
\end{abstract}

Kata Kunci : Penumpang Pesawat; Keterlambatan; Penerbangan.

\begin{abstract}
This paper riset aims to examine and analyze the legal rule regarding airlines for passenger aircraft in Indonesia is Law No. 8 of 1999 concerning Consumer Protection, Law no. 1 of 2009 concerning Aviation and Regulation of the Minister of Transportation No. 89 of 2015 concerning Handling Delays in Scheduled Commercial Air Transport Business Entities in Indonesia and Regulation of the Minister of Transportation Number 92 of 2011 amending the Regulation of the Minister of Transportation No. 77 of 2011 concerning the Responsibility of Air Transport Carriers. The factors causing the delay in departure at Kualanamu Deli Serdang International Airport are one of the factors of weather, and technical problems on aircraft but which are more often caused by weather, especially Kuala Lumpur is the hub airport (collecting airport) of several small airports where the weather can change at any time-Time and it is a thing that often happens in Kuala Lumpur. The responsibility of domestic airlines to aircraft passengers who experience delays in departure at Kualanamu Deli Serdang International Airport is to provide compensation and compensation in the form of soft drinks, snacks and heavy meals as well as compensation, depending on the type of delay according to the category, namely: Category 1, 30 to 60 minutes delay, Category 2, 61 to 120 minutes delay, Category 3, 121 to 180 minutes delay, Category 4, 181 to 240 minutes delay, Category 5, more than 240 minutes delay, Category 6, namely flight cancellations, then the airline is obliged to divert to the next flight or refund all ticket costs. Keywords: Airplane Passenger; Delay; Flight.
\end{abstract}

How to Cite: Yuli, S., Siregar, T., \& Ramadhan, M.C. (2021). Analisis Hukum Terhadap Penumpang Pesawat Atas Keterlambatan Keberangkatan Penerbangan Domestik di Bandara Internasional Kualanamu Deli Serdang. Journal of Education, Humaniora and Social Sciences (JEHSS). 4(2): 1035-1046. 


\section{PENDAHULUAN}

Alat transportasi atau pengangkutan agar bisa mencapai pulau-pulau tersebut dapat menggunakan transportasi darat seperti kereta api, mobil, sepeda motor dan lain-lain, transportasi laut menggunakan kapal laut dan transportasi udara yang menggunakan pesawat udara. Bahkan untuk pulau seperti Kalimantan yang banyak memiliki sungai besar, masyarakat di pulau tersebut menggunakan sungai sebagai jalur transportasi dengan menggunakan perahuperahu kecil. Maka dari itu peran pengangkutan diharapkan dapat memberikan jasa sebaik mungkin sesuai dengan fungsinya, yaitu memindahkan barang maupun orang dari satu tempat ke tempat lain dengan maksud untuk meningkatkan daya guna dan nilai (Soekardono, 2011)

Angkutan udara dewasa ini mengalami perkembangan pesat. Perkembangan dan pertumbuhan industri penerbangan tersebut tidak lepas dari peningkatan jumlah pengguna jasa transportasi udara yang juga mengalami perkembangan pesat. Angkutan udara pada saat ini merupakan alternatif pilihan yang paling efektif karena cepat, efisien, dan ekonomis bagi pengangkutan antar daerah dan antar pulau terutama antara daerah terpencil dan pulau-pulau besar baik pengangkutan barang maupun pengangkutan orang atau penumpang (Saefullah, 2009).

Angkutan udara dewasa ini mengalami perkembangan pesat hal tersebut dapat dilihat dari banyaknya perusahaan maskapai penerbangan baik maskapai penerbangan yang dikelola oleh pihak swasta maupun pihak pemerintah yang biasa disebut dengan Badan Usaha Milik Negara.

Ketepatan waktu dalam penyelenggaraan jadwal penerbangan akan menjadi pertimbangan utama dan juga sebagai tolak ukur kepercayaan para pengguna jasa angkutan udara dikarenakan di era yang serba cepat dan modern ini waktu menjadi prioritas utama, dimana setiap orang jadi sangat menghargai waktu. Sehingga perusahaan penerbangan, termasuk lion air sebagai salah satu perusahaan domestik yang cukup besar, dituntut pula untuk memberikan pelayanan dengan tingkat tampilan tepat waktu yang tinggi (Damas, 2014).

Masalah keterlambatan penerbangan adalah masalah yang memerlukan penanganan yang serius, yang menjadi tanggung jawab keseluruhan unit kerja perusahaan penerbangan salah satunya adalah kegiatan passenger handling. Dikarenakan bahwa dalam perusahaan penerbangan masing-masing kegiatan merupakan satu kesatuan mata rantai yang berintegrasi, dimana apabila satu unit tidak bekerja dengan baik maka akan mempengaruhi pelayanan operasi penerbangan secara keseluruhan.

Pada dasarnya dalam kegiatan pengangkutan udara terdapat dua pihak yang terlibat, yaitu pihak pelaku usaha sebagai penyedia jasa pengangkutan dalam hal ini adalah perusahaan maskapai penerbangan dan pihak konsumen selaku pengguna jasa pengangkutan dalam hal ini yang disebut sebagai penumpang. Pihak penyedia jasa dan pihak pengguna jasa tersebut terikat oleh suatu perjanjian, yakni perjanjian pengangkutan. Pada hakekatnya perjanjian pengangkutan adalah suatu perjanjian, dimana satu pihak menyanggupi untuk dengan aman membawa orang atau barang dari satu tempat ke lain sedangkan pihak yang lain menyanggupi akan membayar ongkosnya. (Saefullah, 2009).

Perjanjian pengangkutan adalah perjanjian timbal balik antara pengangkut dengan penumpang atau pengirim, dimana pengangkut mengikatkan diri untuk menyenggarakan pengangkutan barang atau orang dari suatu tempat tujuan-tujuan tertentu dengan selamat, sedangkan pengirim atau penumpang mengikatkan diri untuk membayar uang angkutan (Subekti, 2015)

Sebagaimana layaknya suatu perjanjian, maka didalam perjanjian pengangkutan antar pihak pengangkut dan pihak pengguna jasa terdapat hubungan hukum bersifat keperdataan yang didalamnya terkandung hak dan kewajiban yang harus dilaksanakan dan dipenuhi.

Salah satu keluhan terbanyak yang disampaikan oleh konsumen selama ini adalah tentang kualitas layanan jasa transportasi penerbangan. Maskapai penerbangan (resminya disebut: badan usaha angkuan udara niaga berjadwal) sudah sangat lazim menunda atau membatalkan secara sepihak penerbangan hanya dengan alasan karena faktor "teknis operasional" (Shidarta, 2018).

Keterlambatan angkutan penerbangan apabila dikaitkan dengan perjanjian pengangkutan, maka pihak pengangkut tidak memenuhi kewajibannya secara baik dan benar atau dapat dikatakan telah melakukan wanprestasi. Dalam hal terjadinya wanprestasi seperti contoh di atas, 
maka pihak penumpang selaku pengguna jasa penerbangan telah dirugikan, baik kerugian materil dan immaterial (Ridwan, 2008).

Apabila terjadi peristiwa atau kejadian yang menyebabkan kerugian bagi penumpang maka akan timbul tanggung jawab hukum dari pihak pengangkut untuk mengganti kerugian yang dialami penumpang. Wujud tanggung jawab yang tersebut adalah berupa pemberian ganti rugi (kompensasi) (Ridwan, 2008).

Ganti rugi yang harus dibayarkan oleh pihak pengangkut dengan dasar bila terlambat datang atau sampai di tempat tujuan, bukan hanya mengenai barang muatan dan bagasi saja, melainkan juga mengenai penumpang. Secara teoritis hubungan hukum antara pihak pengangkut dan pihak penumpang selaku pengguna jasa menghendaki adanya kesetaraan kedudukan diantara para pihak, karena pada dasarnya hubungan antara pengangkut dengan penumpang merupakan hubungan yang bersifat saling ketergantungan. Hanya saja dalam praktek pengangkutan udara hubungan hukum tersebut sering berjalan tidak seimbang, dimana pihak pengangkut sering kali mengabaikan tanggung jawabnya, sehingga menyebabkan penumpang kesulitan untuk mendapatkan hak-haknya sebagai pengguna jasa yang telah dirugikan.

Tujuan penelitian studi ini untuk menganalisis aturan hukum tentang maskapai penerbangan untuk pesawat penumpang di Indonesia, menganalisis faktor-faktor penyebab terjadinya keterlambatan keberangkatan penumpang pesawat di Bandara Internasional Kualanamu Deli Serdang. Untuk menganalisis tanggung jawab maskapai penerbangan domestik terhadap penumpang pesawat yang mengalami keterlambatan keberangkatan di Bandara Internasional Kualanamu Deli Serdang

\section{METODE PENELITIAN}

Pendekatan-pendekatan yang digunakan di dalam penelitian hukum adalah pendekatan undang-undang, pendekatan kasus (Mahmud, 2014), Pendekatan undang-undang dilakukan dengan menelaah semua undang-undang dan regulasi yang bersangkut paut dengan isu hukum yang ditangani dan pendekatan kasus dilakukan dengan cara melakukan telaah kasus-kasus yang berkaitan dengan isu yang dihadapi yang telah menjadi putusan pengadilan yang telah mempunyai kekuatan hukum tetap.

Pendekatan dalam penelitian ini adalah menggunakan pendekatan undang-undang dan juga kasus berdasarkan data-data yang yang diperoleh dari Bandara Internasional Kualanamu Deli Serdang. Sumber data dalam mengerjakan penelitian ini dengan menggunakan data sekunder terdiri dari beberapa bahan hukum untuk melengkapi penelitian antara lain: bahan hukum primer adalah bahan hukum yang mengikat. Dalam penulisan skripsi ini yang menjadi bahan hukum primer adalah Kitab Undang-Undang Hukum Perdata, Undang-Undang No. 8 tahun 1999 tentang Perlindungan Konsumen, Undang-Undang No. 1 Tahun 2009 tentang Penerbangan dan Peraturan Menteri Perhubungan No. 89 Tahun 2015 tentang Penanganan Keterlambatan Pada Badan Usaha Angkutan Udara Niaga Berjadwal Di Indonesia dan Peraturan Menteri Perhubungan Nomor 92 Tahun 2011 perubahan atas Peraturan Menteri Perhubungan No. 77 Tahun 2011 tentang Tanggung Jawab Pengangkut Angkutan Udara. Bahan hukum sekunder adalah bahan hukum yang menjelaskan bahan hukum primer. Dalam penulisan skripsi ini yang menjadi bahan hukum sekunder adalah buku-buku literatur tentang perlindungan hukum dan angkutan udara, hasil-hasil penelitian dan tulisan para ahli hukum, majalah hukum, dan lain-lain. Bahan hukum tersier adalah bahan hukum yang dapat memberikan petunjuk atau penjelasan terhadap bahan hukum primer dan sekunder. Dalam penulisan skripsi ini yang menjadi bahan hukum tersier adalah kamus, ensiklopedia, dan lain sebagainya.

Teknik pengumpulan data dilakukan melalui: Penelitian kepustakaan (Library Research): yaitu dengan mengumpulkan dan mempelajari serta menganalisa konsep-konsep, teori-teori pendapat-pendapat atau penemuan-penemuan serta ketentuan perundang-undangan yang berkaitan dengan hukum. Dokumentasi sebuah acara yang dilakukan untuk menyediakan dokumen-dokumen dengan menggunakan bukti yang akurat dari pencatatan sumber-sumber informasi khusus dari karangan/tulisan, wasiat, buku, undang-undang dan sebagainya. 
Wawancara merupakan percakapan antara dua orang atau lebih dan berlangsung antara sumber dan pewawancara. Tujuan wawancara adalah untuk mendapatkan informasi yang tepat dari narasumber yang terpercaya. Pada Kesempatan ini wawancara dilakukan dengan pihak maskapai di Bandara Internasional Kualanamu Deli Serdang tentang penerbangan yang mengalami keberangkatan.

Analisis data yang digunakan dalam penelitian ini adalah dengan menggunakan metode kualitatif yang menekankan pada pemahaman mengenai masalah-masalah dalam kehidupan sosial berdasarkan kondisi realitas atau natural setting yang holistis, kompleks dan rinci (Syamsul, 2012). Data kualitatif yang diperoleh secara sistematis dan kemudian substansinya dianalisis untuk memperoleh jawaban tentang pokok permasalahan yang akan dibahas dalam penulisan skripsi ini secara kualitatif untuk mendapatkan jawaban yang pasti dan hasil yang akurat. Selanjutnya data yang disusun secara deskriptif sehingga dapat diperoleh gambaran secara menyeluruh terhadap perlindungan hukum penumpang pesawat dan faktor penyebab terjadinya keterlambatan penumpang pesawat. Dan diakhiri dengan penarikan kesimpulan dengan menggunakan metode induktif sebagai jawaban dari permasalahan yang dirumuskan.

\section{HASIL DAN PEMBAHASAN}

Aturan Hukum Tentang Maskapai Penerbangan Untuk Pesawat Penumpang Di Indonesia

Moda transportasi udara memiliki peranan yang penting dan strategis baik dalam perspektif kegiatan bisnis maupun dalam perspektif wawasan nusantara yaitu sebagai sarana penghubung antar daerah. Transportasi udara selain sebagai sarana migrasi atau perpindahan baik manusia maupun barang-barang, juga sebagai sarana penunjang mobilitas para pelaku bisnis dan perdagangan baik dari di tingkat lokal maupun bisnis internasional. Dipilihnya modal transportasi udara karena jenis moda ini memiliki karekteristik, yaitu mampu mencapai tujuan dalam waktu cepat, menggunakan teknologi tinggi, dan memiliki tingkat keselamatan yang tinggi. Akan tetapi dalam kurun waktu beberapa tahun terakhir banyak terdapat peristiwa kecelakaan pada transportasi udara yang memakan atau menimbulkan banyak kerugian baik jiwa maupun harta (Rahayu, 2008)

Dalam menentukan tanggung jawab pengangkut tentunya harus mengacu pada peraturan perundang-undangan sehingga terdapat kepastian hukum, apa bentuk tanggung jawabnya, apa persyaratan untuk dapat bertanggung jawab, berapa besar kerugian yang harus dibayar dan lainlain. Penentuan tanggung jawab perusahaan penerbangan dalam perspektif hukum merupakan sarana bagi perlindungan hukum bagi konsumen pengguna jasa transportasi udara.

Ada beberapa alasan dikeluarkannya Undang-Undang Nomor 8 Tahun 1999 sebagaimana dinyatakan dalam konsiderannya, yaitu; Bahwa pembangunan nasional bertujuan untuk mewujudkan suatu masyarakat adil dan makmur yang merata meteril dan spirituil dalam era demokrasi ekonomi berdasarkan Pancasila dan Undang-Undang Dasar 1945; 1). Bahwa pembangunan perekonomian nasional pada era globalisasi harus dapat mendukung tumbuhnya dunia usaha sehingga mampu menghasilkan beraneka ragam barang dan/atau jasa yang memiliki kandungan teknologi yang dapat meningkatkan kesejahteraan masyarakat banyak dan sekaligus mendapatkan kepastian atas barang dan/atau jasa yang diperoleh dari perdagangan tanpa mengakibatkan kerugian konsumen; 2). Bahwa semakin terbukanya pasar nasional sebagai akibat dari proses globalisasi ekonomi harus tetap menjamin peningkatan kesejahteraan masyarakat serta kepastian atas mutu, jumlah, dam keamanan barang dan/atau jasa yang diperolehnya di pasar; 3). Bahwa untuk meningkatkan harkat dan martabat konsumen perlu meningkatkan kesadaran, pengetahuan, kepedulian, kemampuan, dan kemandirian, konsumen, untuk melindungi dirinya serta menumbuh kembangkan sikap pelaku usaha yang bertanggung jawab; 4). Bahwa ketentuan hukum yang melindungi kepentingan konsumen di Indonesia belum memadai. (Rasyid, 2005)

Selain untuk melindungi konsumen, dengan dibentuk dan diberlakukannya undang-undang tentang perlindungan konsumen juga diharapkan akan memberikan dampak positif bagi perkembangan dunia usaha, yaitu mendukung terciptanya iklim usaha yang sehat dan kondusif bagi perkembangan dan pertumbuhan perekonomian nasional sehingga tujuan pembangunan 
nasional mewujudkan masyarakat adil dan makmur baik materil maupun spiritual akan dapat diwujudkan (AZ, 2014).

Secara nyata adanya kasus-kasus kerugian yang dialami oleh penumpang, dapat dinyatakan bahwa pengangkut atau perusahaan penerbangan telah melanggar ketentuan yang diatur dalam Undang-Undang Nomor 1 Tahun 2009 tentang Penerbangan, Ordonansi Pengangkutan Udara 1939, Undang-Undang Nomor 8 Tahun 1999 Tentang Perlindungan Konsumen.

Menurut Agafta (Setia, 2017) Dalam Pasal 4 Undang-undang Nomor 8 Tahun 1999 tentang Perlindungan Konsumen, dinyatakan Hak konsumen adalah Hak atas kenyamanan, keamanan, dan keselamatan dalam mengkonsumsi barang dan/atau jasa; Hak untuk memilih barang dan/atau jasa serta mendapatkan barang dan/atau jasa tersebut sesuai dengan nilai tukar dan kondisi serta jaminan yang dijanjikan; Hak atas informasi yang benar, jelas, dan jujur mengenai kondisi dan jaminan barang dan/atau jasa; Hak untuk didengar pendapat dan keluhannya atas barang dan/atau jasa yang digunakan; Hak untuk mendapatkan advokasi, perlindungan, dan upaya penyelesaian sengketa perlindungan konsumen secara patut; Hak untuk mendapat pembinaan dan pendidikan konsumen; Hak untuk diperlakukan atau dilayani secara benar dan jujur serta tidak diskriminatif; Hak untuk mendapatkan kompensasi, ganti rugi dan/atau penggantian, apabila barang dan/atau jasa yang diterima tidak sesuai dengan perjanjian atau tidak sebagaimana mestinya; Hak-hak yang diatur dalam ketentuan peraturan perundang-undangan lainnya.

Menurut Undang-undang Nomor 8 Tahun 1999 tentang Perlindungan Konsumen. Pelaku usaha seharusnya memberikan pelayanan terbaik memberikan informasi yang benar, jelas dan jujur mengenai kondisi dan jaminan barang dan/atau jasa serta memberi penjelasan penggunaan, perbaikan dan pemeliharaan; memperlakukan atau melayani konsumen secara benar dan jujur serta tidak diskriminatif, menjamin mutu barang dan/atau jasa yang diproduksi, dan/atau diperdagangkan berdasarkan ketentuan standar mutu barang dan/atau jasa yang berlaku; memberi kompensasi, ganti rugi dan/atau penggantian atas kerugian akibat penggunaan, pemakaian dan pemanfaatan barang dan/atau jasa yang diperdagangkan, memberi kompensasi, ganti rugi dan/atau penggantian apabila barang dan/atau jasa yang diterima atau dimanfaatkan tidak sesuai dengan perjanjian (Indonesia, 1999) .

Perusahaan angkutan udara di Indonesia yang sering mengalami delay berdasarkan data dari Kementrian Perhubungan Republik Indonesia antara lain Lion Air yang dimana mengalami keterlambatan keberangkatan yang berjumlah sebanyak 25.403 kali, lalu maskapai Garuda Indonesia berjumlah sebanyak 11.919 kali. Selain masalah itu, masih banyak kasus yang dialami penumpang seperti barang bawaan dari penumpang yang dirusak seperti pada kasus maskapai Air Asia (Ika, 2017).

Penumpang yang merasa dirugikan oleh pihak perusahaan pengangkut udara mempunyai hak untuk menuntut haknya sebagai penumpang atas peristiwa yang terjadi di dalam ruang lingkup tanggung gugat maskapai penerbangan yang sudah di atur di dalam Undang- Undang penerbangan No 1 tahun 2009 Pasal 146 dan 147 ditentukan bahwa apabila terjadi keterlambatan jadwal penerbangan, maka pihak perusahaan pengangkut udara wajib bertanggung jawab atas kerugian keterlambatan tersebut. Upaya hukum yang dilakukan jika konsumen dirugikan akibat keterlambatan penerbangan adalah mengajukan gugatan ganti rugi atau klaim kepada perusahaan penerbangan (Indonesia, 2009)

Undang- Undang penerbangan No 1 tahun 2009 Pasal 146. Pengangkut bertanggung jawab atas kerugian yang diderita karena keterlambatan pada angkutan penumpang, bagasi, atau kargo, kecuali apabila pengangkut dapat membuktikan bahwa keterlambatan tersebut disebabkan oleh faktor cuaca dan teknis operasional.

Undang- Undang penerbangan No 1 tahun 2009 Pasal 147. Pengangkut bertanggung jawab atas tidak terangkutnya penumpang, sesuai dengan jadwal yang telah ditentukan dengan alasan kapasitas pesawat udara. Tanggung jawab sebagaimana dimaksud pada ayat (1) dengan memberikan kompensasi kepada penumpang berupa: Mengalihkan ke penerbangan lain tanpa membayar biaya tambahan; dan/atau; Memberikan konsumsi, akomodasi, dan biaya transportasi 
apabila tidak ada penerbangan lain ke tempat tujuan; Pengetahuan mengenai hak-hak konsumen wajib diketahui oleh konsumen agar seorang konsumen dapat bertindak secara tegas dan mandiri.

Peraturan Pemerintah Nomor 3 Tahun 2001 dikeluarkan untuk melaksanakan ketentuan dalam Undang-Undang Nomor 1 Tahun 2009 tentang Penerbangan, khusunya mengenai keamanan dan keselamatan penerbangan. Di dalam penjelasannya secara jelas dikemukakan kegiatan penerbangan penuh dengan risiko yang sangat tinggi, sekecil apapun kesalahan yang dilakukan oleh pengangkut dapat berakibat fatal, yaitu terjadinya kecelakaan pesawat yang dapat mengakibatkan kerugian bagi penumpang. Oleh karena itulah masalah keamanan dan keselamatan penerbangan mendapat perhatian serius dalam dunia penerbangan, karena menyangkut jiwa manusia. Peraturan Pemerintah ini secara sistematika terdiri dari 14 Bab 104 Pasal (Indonesia, 2009).

Pada bagian ini dinyatakan bahwa keamanan dan keselamatan penerbangan adalah suatu kondisi untuk mewujudkan penerbangan dilaksanakan secara aman dan selamat sesuai dengan rencana penerbangan. Selanjutnya dipertegas bahwa Keamanan penerbangan adalah keadaan yang terwujud dari penyelenggaraan penerbangan yang bebas dari gangguan dan/atau tindakan yang melawan hukum. Keselamatan penerbangan adalah keadaan yang terwujud dari penyelenggaraan penerbangan yang lancar sesuai dengan prosedur operasi dan persyaratan kelaikan teknis terhadap sarana dan prasarana penerbangan beserta penunjangnya. Dalam pengangkutan udara hal yang terpenting dan mendasar adalah menyangkut keamanan dan keselamatan penerbangan, persoalan keamanan dan keselamatan juga termasuk dalam kerangka perlindungan hukum terhadap penumpang (Rahayu, 2008).

Peraturan Menteri Perhubungan Nomor 92 Tahun 2011 Perubahan Atas Peraturan Menteri Perhubungan Nomor 77 Tahun 2011 tentang Tanggung Jawab Pengangkut Angkutan Udara menetapkan ketentuan serta besaran ganti kerugian kepada penumpang yang mengalami peristiwa keterlambatan maupun pembatalan keberangkatan pesawat udara (Indonesia, 2011) antara lain terdapat dalam beberapa pasal yang akan dipaparkan sebagai berikut:

Pasal 2. Pengangkut yang mengoperasikan pesawat udara wajib bertanggung jawab atas kerugian terhadap: Penumpang yang meninggal dunia, cacat tetap atau luka-luka; Hilang atau rusaknya bagasi kabin; Hilang, musnah atau rusaknya bagasi tercatat; Hilang, musnah atau rusaknya kargo; Keterlambatan angkutan udara; dan Kerugian yang diderita oleh pihak ketiga.

Pasal 9. Keterlambatan angkutan udara terdiri dari; Keterlambatan penerbangan (flight delayed); Tidak terangkutnya penumpang dengan alasan kapasitas pesawat udara (denied boarding passanger); Pembatalan penerbangan (cancelation offlight).

Pasal 10. Jumlah ganti kerugian untuk penumpang atas keterlambatan penerbangan sebagaimana dimaksud dalam Pasal 9 huruf a ditetapkan sebagai berikut; Keterlambatan lebih dari 4 (empat) jam diberikan ganti rugi sebesar Rp. 300.000,00 (tiga ratus ribu rupiah) per penumpang; Diberikan ganti kerugian sebesar 50\% (lima puluh persen) dari ketentuan huruf a apabila pengangkut menawarkan tempat tujuan lain yang terdekat dengan tujuan penerbangan akhir penumpang (re-routing), dan pengangkut wajib menyediakan tiket penerbangan lanjutan atau menyediakan transportasi lain sampai ke tempat tujuan apabila tidak ada moda transportasi selain angkutan udara.

Dalam hal dialihkan kepada penerbangan berikutnya atau penerbangan milik Badan Usaha Niaga Berjadwal lain, penumpang dibebaskan dari biaya tambahan, termasuk peningkatan kelas pelayanan (up grading class) atau apabila terjadi penurunan kelas atau sub kelas pelayanan, maka terhadap penumpang wajib diberikan sisa uang kelebihan dari tiket yang dibeli.

Mengenai keterlambatan penerbangan dan pemberian ganti rugi jika pengangkut bisa menjelaskan bahwa keterlambatan tersebut bukan karena kesalahan pengangangkut maka pengangkut di bebaskan dengan adanya ganti rugi. Dan bila pengangkut tidak bisa menjelaskan tentang faktor keterlambatan itu dikarenakan alasan lain maka pengangkut wajib mengganti kerugian.

Pemberian ganti kerugian akibat keterlambatan penerbangan harus di berikan perusahaan penerbangan kepada konsumen. ganti kerugian tersebut harus diberikan secara sesuai seperti yang sudah di jelaskan oleh peraturan perundang-undangan yang berlaku. Pemerintah juga harus 
ikut serta menegakkan hukum dan memberikan sanksi yang tegas kepada para perusahaan penerbangan yang tidak memenuhi ganti rugi akibat keterlambatan penerbangan.

\section{Faktor-Faktor Penyebab Terjadinya Keterlambatan Keberangkatan Penumpang Pesawat} Di Bandara Internasional Kualanamu Deli Serdang

Keterlambatan (delay) menurut Undang-Undang Nomor 1 Tahun 2009 Tentang Penerbangan Pasal 1 angka 30 adalah terjadinya perbedaan waktu antara waktu keberangkatan atau kedatangan yang dijadwalkan dengan realisasi waktu keberangkatan atau kedatangan, sedangkan pembatalan (cancelation of flight) dapat diartikan sebagai suatu penundaan keberangkatan ataupun pengalihan penerbangan dikarenakan sebab-sebab tertentu (Indonesia, 2009).

Ketentuan mengenai keterlambatan serta pembatalan keberangkatan penumpang diatur dalam Undang-Undang Nomor 1 Tahun 2009 Tentang Penerbangan diantaranya sebagai berikut:

Pasal 146 menyebutkan bahwa "pengangkut bertanggung jawab atas kerugian yang diderita karena keterlambatan pada angkutan penumpang, bagasi, atau kargo, kecuali apabila pengangkut dapat membuktikan bahwa keterlambatan tersebut disebabkan oleh faktor cuaca dan teknis operasional." Selanjutnya; Pengangkut bertanggung jawab atas tidak terangkutnya penumpang, sesuai dengan jadwal yang telah ditentukan dengan alasan kapasitas pesawat udara; Tanggung jawab sebagaimana dimaksud pada ayat (1) dengan memberikan kompensasi kepada penumpang berupa; Mengalihkan ke penerbangan lain tanpa membayar biaya tambahan; dan/atau; Memberikan konsumsi, akomodasi, dan biaya transportasi apabila tidak ada penerbangan lain ke tempat tujuan.

Mengacu kepada Pasal 146 Undang-Undang Nomor 1 Tahun 2009 Tentang Penerbangan, penyebab keterlambatan penerbangan angkutan udara yakni faktor cuaca serta faktor teknis operasional. Menurut penjelasan Pasal 146 maksud dari faktor cuaca antara lain hujan lebat, petir, badai, kabut, asap, jarak pandang di bawah standar minimal, atau kecepatan angin yang melampaui standar maksimal yang mengganggu keselamatan penerbangan, (Indonesia, 2009) selanjutnya yang dimaksud dengan faktor teknis operasional antara lain; Bandara udara untuk keberangkatan dan tujuan tidak dapat digunakan operasional pesawat udara; Lingkungan menuju bandara udara atau landasan terganggu fungsinya misalnya retak, banjir, atau kebakaran; Terjadinya antrian pesawat udara lepas landas (take off), mendarat (landing), atau alokasi waktu keberangkatan (departure slot time) di bandar udara; Keterlambatan pengisian bahan bakar (refuelling).

Sedangkan yang tidak termasuk dengan teknis operasional diantaranya ialah; Keterlambatan pilot, co pilot, dan awak kabin; Keterlambatan jasa boga (catering); Keterlambatan penanganan di darat; Menunggu penumpang, baik yang baru melapor (check in), pindah pesawat (transfer) atau penerbangan lanjutan (connecting flight); Ketidaksiapan pesawat udara.

Dalam Pasal 147 ayat 2 terdapat kalimat "penerbangan lain", yang dimaksud dengan "penerbangan lain" tersebut berdasarkan penjelasan Pasal 147 ialah penerbangan dengan pesawat udara lain milik pengangkut atau pengangkut lainnya. Tentang jenis-jenis dari keterlambatan pengangkutan udara terdapat pada Peraturan Menteri Perhubungan Nomor PM 77 Tahun 2011 sebagaimana telah diubah menjadi Peraturan Menteri Perhubungan Nomor PM 92 Tahun 2011 dimana mengenai jenis-jenis keterlambatan tersebut dapat ditemukan sebagai berikut; Faktor yang menyebabkan keterlambatan penerbangan meliputi: Faktor manajemen airline; Faktor teknis operasional; Faktor cuaca; dan Faktor Lain-lain.

Faktor manajemen airline sebagaimana dimaksud dalam ayat 1 huruf a adalah faktor yang disebabkan oleh maskapai penerbangan, meliputi: Keterlambatan pilot, co pilot, dan awak kabin; Keterlambatan jasa boga (catering); Keterlambatan penanganan di darat; Menunggu penumpang, baik yang baru melapor (check in), pindah pesawat (transfer) atau penerbangan lanjutan (connecting flight); dan Ketidaksiapan pesawat udara.

Faktor teknis operasional sebagaimana dimaksud dalam ayat 1 huruf $\mathrm{b}$ adalah faktor yang disebabkan oleh kondisi bandar udara pada saat keberangkatan atau kedatangan, meliputi: Bandara udara untuk keberangkatan dan tujuan tidak dapat digunakan operasional pesawat 
udara; Lingkungan menuju bandar udara atau landasan terganggu fungsinya misalnya retak, banjir, atau kebakaran; Terjadinya antrian pesawat udara lepas landas (take off), mendarat (landing), atau alokasi waktu keberangkatan (departure slot time) di bandar udara; atau Keterlambatan pengisian bahan bakar (refuelling).

Faktor cuaca sebagaimana dimaksud dalam ayat 1 huruf c, meliputi: Hujan lebat; Banjir; Petir; Badai; Kabut; Asap; Jarak pandang di bawah standar minimal; atau Kecepatan angin yang melampaui standar maksilnal yang mengganggu keselamatan penerbangan.

Faktor lain-lain sebagaimana dimaksud dalam ayat 1 huruf d adalah faktor yang disebabkan diluar faktor manajemen airlines, teknis operasional dan cuaca, antara lain kerusuhan dan/ atau demonstrasi di wilayah bandar udara.

Dalam hal terjadi keterlambatan yang diakibatkan oleh faktor teknis operasional dan faktor cuaca sebagaimana dimaksud pada ayat (3), ayat (4) dan ayat (5) badan usaha angkutan udara wajib menginformasikan dengan bukti surat keterangan resmi dari instansi terkait.

Instansi terkait sebagaimana dimaksud pada ayat (6) adalah otoritas Bandar udara dan unit penyelenggara bandar udara apabila keterlambatan disebabkan faktor teknis operasional dan Badan Meteorologi, Klimatologi dan Geofisika (BMKG) apabila keterlambatan disebabkan faktor cuaca.

Selain itu disebutkan bahwa: Badan Usaha Angkutan Udara bertanggungjawab atas keterlambatan yang disebabkan faktor manajemen airlines sebagaimana dimaksud dalam Pasal 5 ayat (2); Badan Usaha Angkutan Udara dibebaskan dari tanggung jawab atas ganti kerugian akibat keterlambatan penerbangan sebagaimana dimaksud dalam Pasal 5 ayat (3), (4) dan (5).

Badan Usaha Angkutan Udara wajib menyampaikan informasi keterlambatan penerbangan melalui petugas yang berada di ruang tunggu bandar udara yang ditunjuk secara khusus untuk menjelaskan atau memberi keterangan kepada penumpang. Petugas sebagaimana dimaksud pada ayat (1) harus melakukan koordinasi dengan Badan Usaha Angkutan Udara, penyelenggara bandar udara, dan pihak terkait keterlambatan. Informasi kepada penumpang apabila terjadi keterlambatan penerbangan sebagaimana dimaksud pada ayat (1), meliputi: Adanya informasi yang benar dan jelas mengenai alasan keterlambatan penerbangan dan kepastian keberangkatan yang disampaikan kepada penumpang secara langsung melalui telepon atau pesan layanan singkat, atau melalui media pengumuman, selambat-lambatnya 45 (empat puluh lima) menit sebelum jadwal keberangkatan atau sejak pertama kali diketahui adanya keterlambatan; Adanya informasi yang benar dan jelas mengenai pembatalan penerbangan dan kepastian keberangkatan yang disampaikan kepada penumpang secara langsung melalui telepon atau pesan layanan singkat, atau melalui media pengumuman, paling lambat 7 (tujuh) hari kalender sebelum pelaksanaan penerbangan; Dalam hal keterlambatan penerbangan yang disebabkan oleh faktor cuaca, informasi dapat disampaikan kepada penumpang sejak diketahui adanya gangguan cuaca; dan adanya informasi yang benar dan jelas mengenai perubahan jadwal penerbangan (reschedule) yang disampaikan kepada penumpang secara langsung melalui telepon atau pesan layanan singkat, atau melalui media pengumuman, paling lambat 24 (dua puluh empat) jam sebelum pelaksanaan penerbangan.

Badan Usaha Angkutan Udara wajib menyediakan petugas setingkat General Manager, Station Manager, staf lainnya atau pihak yang ditunjuk dan diberikan kewenangan penuh dalam mengambil keputusan di lapangan dalam menangani penumpang yang mengalami keterlambatan penerbangan. Petugas sebagaimana dimaksud pada ayat (1) harus memastikan bahwa dalam memberikan pelayanannya harus: Bersikap empati serta adanya perhatian dan kepedulian; Memberikan kemudahan bagi penumpang yang akan menyusun ulang rencana perjalanan; dan membantu penumpang termasuk pemesanan pulang atau melakukan pemindahan ke penerbangan atau Badan Usaha Angkutan Dalam Negeri lainnya.

Faktor-faktor penyebab terjadinya keterlambatan keberangkatan di bandara Internasional Kualanamu Deli Serdang adalah salah satunya faktor cuaca, dan masalah teknis pada pesawat tapi yang lebih sering di sebabkan karena cuaca apalagi kualanamu merupakan bandara hub (bandara pengumpul) dari beberapa bandara kecil seperti nias, sibolga, dan takengon dimana cuaca bisa berubah sewaktu-waktu dan itu merupakan hal yang sering terjadi di kualanamu (Silalahi, Dkk, 2019). 
Tanggung Jawab Maskapai Penerbangan Domestik Terhadap Penumpang Pesawat Yang Mengalami Keterlambatan Keberangkatan Di Bandara Internasional Kualanamu Deli Serdang

Tanggung jawab berarti kewajiban untuk mengganti kerugian karena suatu tindakan seseorang. Hal tersebut sesuai dengan ketentuan pada Pasal 1365 KUHPerdata. Dalam hukum udara internasional, masalah tanggung jawab telah lama menjadi perhatian (Taufik, 2016)

Masalah yang sering terjadi dan sering dikeluhkan oleh penumpang adalah masalah keterlambatan jadwal penerbangan. Sering kali masalah keterlambatan jadwal penerbangan sudah dianggap hal yang lumrah. Padahal keterlambatan jadwal penerbangan dapat menimbulkan kerugian materiil dan imaterill terhadap penumpang.

Apabila terjadi peristiwa atau kejadian yang menyebabkan kerugian bagi penumpang maka akan timbul tanggung jawab hukum dari pihak pengangkut untuk mengganti kerugian yang dialami penumpang. Wujud tanggung jawab yang tersebut adalah berupa pemberian ganti rugi atau kompensasi. Ganti rugi yang harus dibayarkan oleh pihak pengangkut dengan dasar bila terlambat datang atau sampai di tempat tujuan, bukan hanya mengenai barang muatan dan bagasi saja, melainkan juga mengenai penumpang.

Penumpang memiliki hak dan kewajiban yang telah di jamin oleh undang-undang, dan pengangkutan udara mempunyai hak dan kewajiban yang harus di jalankan, serta penumpang juga harus mengetahui bagaimana mengupayakan dengan baik setiap hak-hak mereka yang harus dipenuhi sesuai peraturan hukum yang berlaku. Yang harus penumpang ketahui juga harus ada payung hukum yang jelas untuk melindungi mereka dan untuk menjamin kepentingan penumpang ketika menggunakan jasa pengangkutan udara (Setia, 2017).

Tanggung jawab adalah merupakan bagian dari kewajiban pelaku usaha dalam melakukan kegiatan usahanya. Tanggung jawab ini juga disebut dengan istilah tanggung gugat produk (Product Liability). Yang dimaksud dengan product liability adalah bahwa pelaku usaha bertanggung jawab atas segala kerugian yang timbul dari hasil produk/jasanya. Kerugian yang diderita seseorang secara garis besar dapat dibagi atas 2 (dua) bagian, yaitu kerugian yang menimpa diri dan kerugian yang menimpa harta benda seseorang.

Sedangkan kerugian harta benda sendiri dapat berupa kerugian nyata yang dialami serta kehilangan keuntungan yang diharapkan. Dalam penyelenggaraan pengangkutan udara, masalah tanggung jawab pengangkut adalah faktor yang sangat penting. Seperti diketahui dalam penyelenggaraan pengangkutan udara, banyak pihak yang terlibat, sehingga perlu diketahui sejauh mana tanggung jawab tersebut dalam penyelenggaraan pengangkutan udara itu. Dalam Undang-Undang Penerbangan, tanggung jawab pengangkut yang digunakan ada 3 (tiga) prinsip tanggung jawab, yaitu; Prinsip Tanggung Jawab Atas Dasar Kesalahan (Liability Based on Fault or Negligence); Prinsip Tanggung Jawab Praduga Bersalah (Presumption Of Liability); dan Prinsip Tanggung Jawab Mutlak (Strict Liability atau Absolute of Liability). (Happy, 2008)

Perbedaan dari ketiga prinsip tanggung jawab tersebut terletak pada masalah pembuktian, yaitu mengenai ada tidaknya kewajiban pembuktian, dan kepada siapa beban pembuktian diletakkan dalam proses penuntutan (Ridwan, 2008) yaitu prinsip tanggung jawab atas dasar kesalahan dalam ditekankan bahwa tiada tanggung jawab tanpa kesalahan.

Adapun yang dimaksud dengan kesalahan adalah perbuatan yang disengaja maupun kelalaian. Yang menjadi ukuran perbuatan pelaku usaha adalah perbuatan manusia normal yang dapat membedakan kapan dia harus melakukan sesuatu dan kapan dia tidak boleh melakukan sesuatu. (Saefullah, 2009)

Prinsip tanggung jawab berdasarkan kesalahan pada dasarnya mengandung 2 (dua) aspek, yaitu adalah adil bagi pihak yang telah menimbulkan kerugian untuk member kompensasi kepada pihak yang mengalami kerugian dan adil apabila pihak yang menyebabkan kerugian kepada orang lain namun bukan karena kesalahannya untuk tidak memberikan kompensasi kepada pihak yang merasa dirugikan.

Prinsip ini lebih menekankan pada aspek yang pertama, yaitu apabila terbukti ada kesalahan, maka korban berhak untuk mendapatkan kompensasi ganti rugi. Karena alasan 
tersebut, beban pembuktian menjadi unsur penting dalam prinsip tanggung jawab ini dan beban pembuktian tersebut ada pada pihak korban, yaitu konsumen. Hal tersebut mengakibatkan apabila konsumen ingin menuntut ganti rugi dari pelaku usaha, maka konsumen harus dapat membuktikan bahwa kerugian yang diderita adalah akibat dari kesalahan pelaku usaha. Jadi, dalam hal ini apabila penumpang gagal membuktikan adanya unsur kesalahan dari maskapai penerbangan tentang keterlambatan jadwal penerbangan, maka maskapai penerbangan berhak untuk tidak memberikan kompensasi ganti kerugian. Bagi penumpang, bukan persoalan mudah untuk dapat membuktikan kesalahan dari maskapai penerbangan (Abdulkadir, 2018).

Prinsip Tanggung Jawab Praduga Bersalah Prinsip tanggung jawab praduga bersalah diterapkan dalam Konvensi Warsawa dan Ordonansi Pengangkutan Udara.

Perbedaan utama antara prinsip tanggung jawab ini dengan sistem tanggung jawab atas dasar kesalahan terletak pada beban pembuktian. Beban pembuktian pada prinsip ini terletak pada pihak pelaku usaha. Dalam prinsip ini, pelaku usaha dalam hal ini maskapai penerbangan sebagai pihak pengangkut dianggap selalu bertanggung jawab atas semua kerugian yang timbul pada pengangkutan yang diselenggarakan. Akan tetapi apabila dalam proses pembuktian, dapat dibuktikan bahwa maskapai penerbangan tidak bersalah atau telah melakukan suatu tindakan yang diperlukan untuk menghindari segala kerugian, maka maskapai penerbangan akan dibebaskan dari segala tanggung jawab untuk ganti kerugian (Rahayu, 2008).

Dalam hal ini, apabila penumpang mengalami kerugian karena keterlambatan jadwal penerbangan, penumpang tidak perlu membuktikan kesalahan dari maskapai, cukup hanya menunjukkan bahwa kerugian yang dideritanya tersebut terjadi selama menunggu pesawat yang terlambat.

Diberlakukannya prinsip ini karena mustahil kiranya bagi penumpang selaku pengguna dapat membuktikan kesalahan dari pihak pengangkut tentang sebab-sebab keterlambatan, misalnya seperti adanya kelalaian pemeliharaan pesawat maupun alasan teknis lainnya seperti ketentuan menurut prinsip tanggung jawab atas dasar kesalahan. Karena itulah baik konvensi Warsawa maupun Ordonansi Pengangkutan Udara meletakkan beban pembuktian pada pihak maskapai. Dengan adanya pembalikan beban pembuktian, prinsip tanggung jawab ini diiringi oleh ketentuan pembatasan tanggung jawab ganti kerugian (Sitorus, Dkk, 2020).

Dalam tanggung jawab mutlak (Strict Liability), yakni unsur kesalahan tidak perlu dibuktikan oleh pihak penggugat sebagai dasar ganti kerugian, ketentuan ini merupakan Lex Specialis dalam gugatan tentang perbuatan melanggar hukum pada umumnya. Sebaliknya Absolute Liability adalah prinsip tanggung jawab tanpa kesalahan dan tidak ada pengecualiannya (H.M.N, 2015).

Menurut prinsip tanggung jawab mutlak, pengangkut dianggap selalu bertanggung jawab atas setiap kerugian yang timbul atas peristiwa apapun selama penyelenggaraan pengangkutan. Tidak ada beban kewajiban atas pembuktian kesalahan. Didalam tanggung jawab mutlak ditentukan batasan mengenai jumlah ganti rugi yang akan diberikan oleh pihak tergugat, dalam hal ini adalah maskapai penerbangan selaku pihak pengangkut. Akan tetapi dimungkinkan adanya hal-hal yang dapat membebaskan maskapai penerbangan dari kewajiban atas ganti kerugian.

Prinsip ini digunakan dalam Pasal 43 ayat (1) dan (2) Undang-Undang Penerbangan. Penerapan prinsip ini cukup memberikan perlindungan yang proporsional baik bagi maskapai selaku pihak pengangkut maupun bagi penumpang selaku pihak pengguna jasa angkutan udara. Hal tersebut dikarenakan adanya batasan mengenai besarnya jumlah ganti rugi yang harus dibayarkan oleh maskapai yang tidak dapat dilampaui besaran nilainya dalam keadaan apapun.

Tanggung jawab pihak maskapai penerbangan menurut Peraturan Menteri Perhubungan Nomor 92 Tahun 2011 Tentang Perubahan atas ketentuan Peraturan Menteri Nomor 77 Tahun 2011 juga menyebutkan bahwa Tanggung jawab pengangkut dalam peraturan ini berlaku juga terhadap pengangkut yang melakukan kegiatan angkutan udara niaga tidak berjadwal (charter) atau pihak-pihak lain sebagai pembuat kontrak pengangkutan (contracting carrier) sepanjang tidak diperjanjikan lain dan tidak bertentangan dengan peraturan ini. Ada beberapa faktor yang mengakibatkan maskapai penerbangan dibenarkan untuk melakukan penundaan jadwal penerbangan. Faktor-faktor tersebut adalah faktor cuaca dan faktor teknis. Diluar dari faktorfaktor tersebut, tidak dibenarkan bagi maskapai untuk menunda jadwal penerbangan. 


\section{SIMPULAN}

Berdasarkan pemaparan hasil dari penelitian di atas maka dapat di tarik kesimpulan berdasarkan rumusan masalah yang dibahas yaitu bahwa tentang Aturan hukum tentang maskapai penerbangan untuk pesawat penumpang di Indonesia adalah Undang-Undang No. 8 tahun 1999 tentang Perlindungan Konsumen, Undang-Undang No. 1 Tahun 2009 tentang Penerbangan dan Peraturan Menteri Perhubungan No. 89 Tahun 2015 tentang Penanganan Keterlambatan Pada Badan Usaha Angkutan Udara Niaga Berjadwal Di Indonesia dan Peraturan Menteri Perhubungan Nomor 92 Tahun 2011 perubahan atas Peraturan Menteri Perhubungan No. 77 Tahun 2011 tentang Tanggung Jawab Pengangkut Angkutan Udara.

Faktor-faktor penyebab terjadinya keterlambatan keberangkatan di Bandara Internasional Kualanamu Deli Serdang adalah salah satunya faktor cuaca, dan masalah teknis pada pesawat tapi yang lebih sering di sebabkan karena cuaca apalagi kualanamu merupakan bandara hub (bandara pengumpul) dari beberapa bandara kecil seperti nias, sibolga, dan takengon dimana cuaca bisa berubah sewaktu-waktu dan itu merupakan hal yang sering terjadi di kualanamu.

Tanggung jawab maskapai penerbangan domestik terhadap penumpang pesawat yang mengalami keterlambatan keberangkatan di Bandara Internasional Kualanamu Deli Serdang adalah dengan memberikan konpensasi dan ganti rugi yaitu berupa minuman ringan, makanan ringan dan makanan berat serta uang ganti rugi, tergantung jenis keterlambatan menurut kategorinya yaitu: Kategori 1, keterlambatan 30 sampai 60 menit, kompensasi berupa minuman ringan. Kategori 2, keterlambatan 61 sampai 120 menit, kompensasi berupa makanan dan minuman ringan (snack box). Kategori 3, keterlambatan 121 sampai 180 menit, kompensasi berupa minuman dan makanan berat. Kategori 4, keterlambatan 181 sampai 240 menit, kompensasi berupa makanan dan minuman ringan serta makanan berat. Kategori 5, keterlambatan lebih dari 240 menit, kompensasi berupa ganti rugi sebesar Rp 300 ribu. Kategori 6, yaitu pembatalan penerbangan, maka maskapai penerbangan wajib mengalihkan ke penerbangan berikutnya atau mengembalikan seluruh biaya tiket (refund).

\section{DAFTAR PUSTAKA}

Abdulkadir, M. (2018). Hukum Pengangkutan Niaga, Bandung: PT. Citra Aditya Bakti.

AZ, N. (2014). Hukum Perlindungan Konsumen di Indonesia. Bandung: PT. Citra Adiya Bakti.

Damas, P. R. (2014). Perlindungan Konsumen Terhadap Keterlambatan Penerbangan (Flight Delay),. Jurnal Hukum Bisnis, Volume II.

H.M.N, P. ( 2015). Pengertian Pokok Hukum Dagang Indonesia, 3, Hukum Pengangkutan. Jakarta: Penerbit Djambatan.

Happy, S. (2008). Hak-hak Konsumen Jika Dirugikan. Jakarta: Transmedia Pustaka.

Ika, D. N. (2017). Pelaksanaan Tanggung Jawab Maskapai Penerbangan Terhadap Keterlambatan Penerbangan, Bagian Hukum Bisnis. Bali: Fakultas Hukum, Universitas Udayana.

Indonesia. (1999). Undang-Undang No. 8 tahun 1999 tentang Perlindungan Konsumen. Jakarta: Republik Indonesia.

Indonesia. (2009). Undang-Undang No. 1 Tahun 2009 tentang Penerbangan. Jakarta: Republlik Indonesia.

Indonesia. (2011). Peraturan Menteri Perhubungan Nomor 92 Tahun 2011 perubahan atas Peraturan Menteri Perhubungan No. 77 Tahun 2011 tentang Tanggung Jawab Pengangkut Angkutan Udara. Jakarta: Republik Indonesia.

Mahmud, M. P. (2014). Pengantar Ilmu Hukum. Jakarta: Kencana Pranada Media Group.

Rahayu, H. (2008). Hukum Pengangkutan. Malang: UMM Pers.

Rasyid, S. A. (2005). Hukum Bisnis Untuk Perusahaan. Jakarta: Kencana.

Ridwan, K. (2008). Tanggung Jawab Pengangkut dan Asuransi Tanggung Jawab Sebagai Instrumen Perlindungan Konsumen Angkutan Udara, . Yogyakarta: Liberty.

Saefullah, W. E. (2009). Tanggung Jawab Pengangkut Dalam Hukum Pengangkutan Udara Internasional Dan Nasional, . Yogyakarta: Liberty. 
Setia, A. M. (2017). Tanggung Jawab Maskapai Penerbangan Terhadap Keterlambatan Penerbangan, Mimbar Keadilan Jurnal Ilmu Hukum. Surabaya: Fakultas Hukum Universitas 17 Agustus 1945 Surabaya.

Shidarta. (2018). Keterlambatan dan Pembatalan Penerbangan. Jakarta: Fakultas Bisnis Bina Nusantara.

Silalahi, S.D, Munawir, Z \& Syaputra, M.Y.A, (2019). Perlindungan Hukum Bagi Pekerja Kontrak Yang Mengalami Pemutusan Hubungan Kerja Pada Masa Kontrak (Studi Kasus Putusan Nomor : 82/Pdt.Sus-Phi/2016/PN. Mdn). JUNCTO, 1(2) 2019: 174-182,

Sitorus, J., Zulyadi, R. \& Trisna, W. (2020). Perlindungan Hukum Terhadap Korban Tindak Pidana Pencurian Ditinjau Dari Kajian Victimlogi (Studi Putusan No : 20/Pid.B/2017/PN. Mdn). JUNCTO, 2(1) 2020: 41-50

Soekardono, R. (2011). Hukum Dagang Indonesia jilid 1. Jakarta: Rajawali Press.

Subekti, R. (2015). Aneka Perjanjian. Bandung: PT. Citra Aditya Bakti.

Syamsul, A. (2012). Metode Penulisan Karya Ilmiah dan Penelitian Hukum. Medan : Area University Press.

Taufik, H. M. (2016). Perlindungan Hukum Terhadap Pengguna Jasa Angkutan Udara Dalam Perspektif Peraturan Perundang-Undangan Tentang Penerbangan. Jurnal Hukum, Volume VIII Nomor 3. 